\title{
S-Phase Fraction
}

National Cancer Institute

\section{Source}

National Cancer Institute. S-Phase Fraction. NCI Thesaurus. Code C18456.

The percentage of cells in a sample currently undergoing mitosis. 